\title{
3 The memory of national literature in Budapest city \\ 4 centre
}

\section{Péter Hajdu}

6

7 (C) Akadémiai Kiadó, Budapest, Hungary 2014

A cityscape may express ideological messages in many different ways, from the organization of public space through the names and looks of important buildings (with the techniques of emphasising their importance or rather making them important), to directly verbalized utterances written on durable or perishable materials. In the following discussion, however, I will focus on two features which may be loaded from the viewpoint of ideology, namely street names and public monuments. Budapest, the city as we know it, was founded and given this name in 1872 through the unification of three towns, namely Buda, Óbuda and Pest. The structure of the new, would-be metropolis developed in the following decades, and most of the buildings of the city centre were built in that period. The population increased from 270,000 in 1869 to 880,000 in 1910 (Romsics 2000, p. 65). It was the fastest developing capital in Europe at that time (Bertényi and Gyapay 1993, p. 451). The second boom in the growth of the city happened in the 1950s, when the 


\begin{tabular}{|l|lll|}
\hline & Journal : 11059 & Dispatch : 8-5-2014 & Pages : 8 \\
Article No. : 219 & $\square$ LE & $\square$ TYPESET \\
MS Code : & $\square$ CP & $\square$ DISK \\
\hline
\end{tabular}

communist regime decided to create a large-scale industry centre for the country. An important factor in this second enlargement was the incorporation of three nearby towns (Újpest, Kispest, and Rákospalota) and a number of villages. The result was a city of 2 million inhabitants, which was disproportionately large for a country of 10 million. It is obvious, however, that the second enlargement was much more interested in quantity than in transforming the general look of the city, and focused rather on the peripheral areas. The Budapest we usually think of and, with rare exceptions, all the important features of its mental map, were developed around the end of the nineteenth century.

The city design of that period transformed the public space into a monument of national history, which can also be read from the street names. A fair number of streets still keeps their organic, medieval denominations, especially in the real historical core of the city, and such names as Fövám tér or Régiposta utca (Main Tax Office Square, and Old Post Office Street, respectively)_preserving the memory of long-gone office buildings_-or Sas utca, Kígyó utca (Eagle, and Snake Streets) —after inns demolished long ago-or Molnár utca, Sütö utca, Aranykéz utca (Miller, Baker, and Golden Hand Streets)—named after professions or shops once typical there-are now protected by law as part of the urban heritage. At the end of the nineteenth century, however, many streets were given new names that fitted better into the cultural-ideological climate. Political issues played a central role in the new metropolitan space, but emphasis was also laid on cultural achievement. Most of the street names cherish the memory of kings, generals and politicians, ${ }^{1}$ but there were also some artists who were regarded as being qualified to give their names to some streets or squares. Although this tendency continued into the twentieth century, nineteenth century names prevail in Budapest's streets, just like nineteenth century figures in the city's public monuments. When twentieth century authorities decided to rename some streets, they tended to choose nineteenth century figures. The city centre is a monument to the great nation building project, as the glamour of the capital was planned to show pride in the success of nation building, and further ambitions. The proportions are telling. In the fifth district, which is the real heart of the city, 34 streets are named after rulers, soldiers and politicians, and 19 after artists. The artists include an actress (Jászai), a musician (Bihari), a composer (Kálmán), two architects (Steindl and Hild), and a sculptor (Ferenczy), and maybe a painter (Markó), but no less than 11 writers. (To do the sums correctly, one needs to know that the national poet Sándor Petôfi has both a street and a square in the fifth district - and 17 other streets in Budapest.) Among all these authors we can find only one twentieth-century poet (Attila József), while seven of them lived in the nineteenth century. If we look at the whole city centre (inside the boulevard), the odds are more equal: 27 persons of the ruler-soldier-politician persuasion, and 26 artists, 16 of them being writers. This result is strongly influenced by the neighbourhoods around the opera house and the nineteenth century Academy of Music, which led people to name some streets after musicians around there. The nineteenth century prevails among these authors even more strongly: only one eighteenth century poet could make his way into this group. To be fair, it should be said that some also wrote influential

\footnotetext{
${ }^{1}$ Apart from some local celebrities, such as Károly Vajkay, an influential lawyer, whose name was given to the street he had lived in.
} 


\begin{tabular}{|l|lll|}
\hline & Journal : 11059 & Dispatch : $\mathbf{8 - 5 - 2 0 1 4}$ & Pages : 8 \\
Article No. : 219 & $\square$ LE & $\square$ TYPESET \\
MS Code : & $\square$ CP & $\square$ DISK \\
\hline
\end{tabular}

The memory of national literature

works at the beginning of the twentieth century. In this area we find one street baptised after a non-Hungarian author, Alexander Pushkin. ${ }^{2}$

Literature, however, appears in this context as a political issue too. The statue of Mihály Vörösmarty (1800-1855) may be a case in point. It was erected in 1908 in the very centre of Budapest on a square that was also named after him in 1926. The poet is represented sitting in an armchair as a giant figure towering over a set of minor figures (even these are approximately $50 \%$ bigger than life size) who represent society as a whole (farmers, labourers, gentlemen) listening to his poetry, or rather to the version set to music of two introductory stanzas of a poem by him. Vörösmarty was a brilliant romantic poet who composed a huge body of lyric poetry, many dramas, and an impressive set of epics. His name, however, is not indicated in this statue at all. The inscription on the monument is the two first lines of his poem "Appeal" (Vörösmarty 1836), the beginning of which functions as the second national anthem of Hungary.

\section{To your homeland without fail}

\section{Be faithful, O Hungarian!}

It is your cradle and will your grave be

Which nurses, and will bury you.

In the great world outside of here

Where is no place for you

May fortune's hand bless or beat you

Here you must live and die!

The lines in italics are carved in the marble of the statue, and these two of the poem's fourteen stanzas were set to music by Béni Egressy in 1843. This monument does not represent a poet of great imagination, not even a poet as the author of a complete poem; it is rather a monument to the "Appeal" and the nation's unity in the solemn moment of singing it. The only merit for which the poet is to be remembered is that he wrote the text of the song which offers to the members of the community an opportunity to experience the sublime feeling of their national identity. Even if the monument was erected in 1908, his achievement has been presented exclusively in the national-political context. It is not a falsification, to be sure, but rather a restriction, since Vörösmarty really did contribute to the nation building project through many of his works, but a huge body of his production can hardly be interpreted from this viewpoint.

\footnotetext{
2 The street was given this name in the 1950s, during the communist period. Previously it was called Esterházy Street. The communist regime did not accept the name of an aristocratic family (which they associated with centuries of oppression) in the city centre. Many of such re-nominations were withdrawn after 1989, but not all of them by far. The name of the Esterházy family was not really important in the 1990s (and, for what it is worth, could have been associated with two living members, a footballer who was also member of the national team, and the excellent, but still living, prose writer), and Pushkin seemed still acceptable. Although being Russian might have been the main reason why he had a street in the 1950s, he could not be associated with communism, therefore the name could stand. A couple of nonHungarian writers have streets after them a little north of the city centre. They were regarded as representatives of "critical realism" highly esteemed by communists, as Balzac, Hugo, and Gogol.
} 


\begin{tabular}{|l|lll|}
\hline & Journal : 11059 & Dispatch : 8-5-2014 & Pages : 8 \\
Article No. : 219 & $\square$ LE & $\square$ TYPESET \\
MS Code : & $\square$ CP & $\square$ DISK \\
\hline
\end{tabular}

Some streets advertise local past or pride. Particularly relevant is a more sophisticated example, in which local memory, national ideology and literary affairs intertwine. A small street in the heart of the city is called Mihály Vitkovics Street. Vitkovics (1778-1829) was a minor poet and an organizer of literary life. Apart from the name nothing connects this street to his person. There is, however, a memorial plaque a kilometre away from here, erected in 1932. The inscription says: "Here stood the house in which Mihály Vitkovics, prose writer and poet gathered between 1812 and 1829 writers and scholars of the age of the Hungarian boom, hosting those working to elaborate the Hungarian language, to promote national perfection, and to make Pest a literary centre." The plaque celebrates him as a figure of national development, but explicitly as a poet too. Or rather the plaque celebrates him as host, and his house as the place where literary life started developing, which is important, since a "perfect nation" must have literature too.

The most important historical events to be remembered in the Budapest cityscape were the 1848-1849 revolution and the national war of independence. There are two important foci of the materialisation of this memory. The first is a place in the area now called Lipótváros, the Hungarian translation of the nineteenth century German Leopoldstadt. This area was situated to the north of the historical city centre, but still inside the city wall. It was developed in the last decades of the eighteenth century, and received its name in 1790, when Leopold II was crowned king of Hungary. Nowadays it is the administrative and financial centre of the country, but until 1897 its most impressive building was a huge military complex and prison called Neugebäude, the symbol of Habsburg oppression. When it was demolished, its site was transformed into a monument of anti-Habsburg resistance. A large square was created with a ground-plan similar to that of a basilica, and given the name Liberty. Four streets leading out of its apse were named after generals who had fought against the Habsburgs. Three of them (Ernô Kiss, Károly Vécsey and Lajos Aulich) were executed on 6th October 1849 in Arad. Mór Perczel was also a general of the Hungarian army, but in the final weeks he had some conflicts with the political leaders, especially with governor Lajos Kossuth, and was relieved of command. Nevertheless he fought till the last minute, at which he found himself on the Turkish border, giving him an opportunity to escape. In 1851 he was sentenced to death in contumaciam, but after the Compromise he returned to Hungary, where he died in 1899. The street which extends the axis of the square is called Honvéd. This word was coined in 1821, and means soldier, but not in the general sense. According to the dictionary it has or had three meanings with historical differences: "honvéd" may refer first to a soldier of the Hungarian army in the period 18481849. Second, it may mean a soldier of the Hungarian army between 1868 and 1918 (Austria and Hungary had a common army with German as the language of command, and separate armies for each country, Landwehr for Austria and honvédség for Hungary with Hungarian as the language of command; but only those men were allowed to join the latter that had not met the standards of recruitment for the common army). Finally, it may mean a private in the army of independent Hungary (after 1918). This is the meaning of the name of the street now. Around 1900 the association with the army of the anti-Habsburg independence war was much stronger. There were, for example, "honvéd associations" all around the 


\begin{tabular}{|l|lll|}
\hline & Journal : 11059 & Dispatch : $\mathbf{8 - 5 - 2 0 1 4}$ & Pages : 8 \\
Article No. : 219 & $\square$ LE & $\square$ TYPESET \\
MS Code : & $\square$ CP & $\square$ DISK \\
\hline
\end{tabular}

The memory of national literature

country for people that fought in the Hungarian army in 1848-1849. The street that seems to continue Honvéd Street on the other end of the square is called October 6th Street, commemorating the day when 13 generals of Hungarian army (remembered as the martyrs of Arad) were executed.

In addition to the street names a monument was constructed to commemorate the war of independence. The first prime minister of Hungary, Count Lajos Batthyány, was executed by the wall of the Neugebäude on 6th October 1849. The Budapest city council decided in 1906 that on the spot of his death a monument with an eternal flame should be installed. However, it was not inaugurated until 1926, when Liberty Square was already loaded with new ideological content. Even if national independence remained a rather important value in the period after World War I, that regime did not cherish the memory of 1848 . The new ideology was based on the trauma of the dismemberment of the Hungarian Kingdom and regarded nineteenth century liberalism as the main reason for the collapse. Those in power therefore did not feel comfortable with the memory of a liberal revolution. In 1921 an irredentist monument was erected in the semicircular northern end the square, four groups of statues representing the various irredentas. In 1928 a new element was added to the composition, the so-called "national flag with relics." The relics were pieces of soil from the irredentas contained by the pedestal, and the flag was always at half-mast to express national mourning. The name "Liberty" in this new context was supposed to mean the liberty of which the Hungarians in Austria, Czechoslovakia, Romania and Yugoslavia were deprived.

The monument of irredentism was destroyed in 1945, and one year later a Monument of the Soviet Heroes was erected in the place of the national flag. In that re-interpretation, liberty meant the Soviet liberation of Hungary, both from German occupation and inner oppression. It is still a topic of discussion, since those liberators did not leave the country until 1989. For many people it still can be considered as liberation, if regarded separately from the installation of a communist dictatorship in the following years, but for the majority, Russian invasion was just another conquest. For them a Soviet monument on Liberty square was a cruel irony. After 1989 all the Soviet monuments in Budapest were removed except this one. Its persistence is guaranteed by interstate agreement between Russia and Hungary. Although the extreme right regards its existence as an insult, and actually nobody likes it, it will stay there for a long while to come. The current rightist local government, however, tried to create a new balance by erecting a statue of Ronald Reagan in the square in 2011, on the 100th anniversary of his birth. Since the statue has no pedestal, and is only $19 \%$ higher that life size, it gives the impression that the president is walking across Liberty square to see the Soviet Heroic Monument, or going to the American embassy passing by the monument. In any case, the Soviet Monument is now situated between the Embassy of the USA and the statue of Ronald Reagan, which makes the Liberty square into a monument of the cold war. The names of streets leading to its apse still preserve the memory of its original meaning associated with $1848-1849$.

On the other end of the historical city centre we find another memory complex of the revolution of 15th March 1848 with much more literary motives. Petöfi Square and March 15th Square create a unified space now. The former received this 


\begin{tabular}{|l|lll|}
\hline & Journal : 11059 & Dispatch : 8-5-2014 & Pages : 8 \\
Article No. : 219 & $\square$ LE & $\square$ TYPESET \\
MS Code : & $\square$ CP & $\square$ DISK \\
\hline
\end{tabular}

denomination around 1870, the latter only in 1948, for the 100th anniversary. Sándor Petöfi is the national poet of Hungary and the emblematic figure of the revolution. His statue was erected in his square in 1882, as a result of a civil initiative. It is reasonable enough that he has a statue and a square in the city centre. He was a great poet, who left behind a huge, very rich and colourful oeuvre. The statue represents him as presenting his National Song to the revolutionary crowd on the steps of the National Museum. Even if he wears nineteenth century clothes, his coat creates the impression-when viewed from a certain angle-that he is a Roman tribune perorating. A poet, to be sure, but in direct contact with his audience in a rare moment when poetry is a direct political action. The street which starts from March 15th Square is called the Road of the Free Press. This name was given after World War II, also cherishing the memory of the revolution. Since censorship was abolished on that revolutionary day for the first time in Hungarian history, journalists (a category which used to include the vast majority of people producing literature) celebrated the freedom of speech on the 15th March in the era of dualism. Its continuation is named after Lajos Kossuth, the leader of the independence war. The city authorities decided to give the street this name about the time when the exiled revolutionary leader was deprived of his Hungarian citizenship in 1889. At the transition point, a street begins which was called Crown-prince Street until 1923. Since that time it is called Sándor Petôfi Street. While the memorial place of 18481849 was created at once around the Liberty Square, and it has more or less lost its meaning through the course of history, this second one has slowly developed starting with Petőfi's square and statue.

In the case of erecting a public monument, the lack of explicit ideological message implies a message. János Arany (1817-1882) was the most prestigious poet of the second half of the nineteenth century. The street in which he was living in Budapest is named after him. We have to admit, however, that Arany was the chief secretary of the Hungarian Academy of Sciences between 1865 and 1877, and due to this function he had a department in its headquarters, which he was allowed to use even after he retired. Therefore the denomination celebrates him also as an organizer of an institute that used to have central importance in the nation's cultural politics. ${ }^{3}$ There is also a statue to Arany two kilometres away, in front of the National Museum, which was erected in 1893. It represents him as a genuine poet, sitting in an armchair, with fictional figures from his epics as accessories. One may ask, however, why Arany is sitting in front of the National Museum, while Petôfi is standing more than a kilometre away in a pose which presents him as if he was here? The building of the National Museum functioned as the House of Lords between 1867 and 1902, while the House of Commons was located in the neighbouring Sándor Street. It is only logical that a revolutionary figure like Petőfi could not be allowed to stand in front of the House of Lords. Arany was much more acceptable.

In 1896 both houses of the Hungarian parliament moved to the new building still under construction in Leopoldstadt. Before discussing their new location in some detail, let me mention that Sándor Street received a new name in 1940. The name

\footnotetext{
3 The gesture of Count Széchenyi in 1825, when he suggested establishing a Hungarian academy of sciences and started funding it, is regarded as the beginning of the Hungarian awakening.
} 


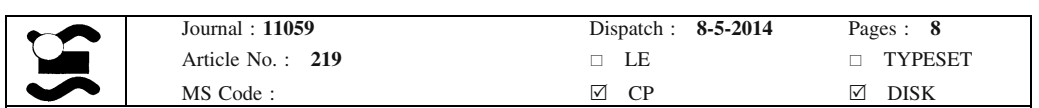

The memory of national literature

243 Sándor is nothing special; it is just the Hungarian version of Alexander. In some 244 periods, however, the street name was Archduke Sándor, since it was originally 245 named after Erzherzog Alexander Leopold Johann Joseph von Habsburg (1772246 1795). Nowadays it is called Sándor Bródy Street, after an excellent prose writer and playwright active around the turn of the century (1863-1924).

Since 1902 the Hungarian parliament has been housed in a building overlooking the Danube, although its construction was not completely finished until 1904. The 250 area around the building became the most important place in Hungary from an ideological viewpoint. It has been called Kossuth Square since 1927, and its monographer called it spiritually and symbolically overloaded (Gerő 2008, p. 78). In 2011 there were five statues, one statue group, four other historical monuments, plus the state flag there. The four non-statuesque monuments are dedicated to the memory of the victims of the massacre that happened on 25th October 1956 when unidentified groups began shooting at a peaceful demonstration, killing 60-70 and injuring 100-150 people. The statue group represents Kossuth and the first Hungarian government, two other statues in important spots represented influential politicians from Hungarian history, two statues in rather peripheral positions 260 represent third rank politicians of the twentieth century that were important for some groups in given historical moments. And last but not least, there is the statue of Attila József, an outstanding lyric poet from the twentieth century. How does a poet come to be here, where "everything is always about power, directly or indirectly, demonstrating or challenging it"? (Gerô 2008, p. 80) The statue is located on the spot where the very first statue of the square used to stand, that of Gyula Andrássy, the first prime minister of Hungary after the Compromise, and the minister for foreign affairs of Austria-Hungary for decades. The statue was destroyed in World War II, and the site remained vacant till 1980, the seventy-fifth birthday of Attila József. On the one hand, the communist regime liked the poet, who for a couple of years was member of the illegal communist party, writing some poems of commitment; on the other hand, it was already the soft dictatorship of János Kádár, based on the principle "who is not against us, is with us", which is a perfect match for a poet quietly sitting and reasoning. His statue, however, creates a harsh contrast to the other monuments of the square. Not a member of the elite, but an obviously poor man, not a performer of historical deeds, but a thinker, not in a solemn pose and not even looking at the centre of the square, which is also the symbolic centre of the Hungarian politics. He turns his back to that symbolic political stage, and looks out over the Danube. And one more thing. All the other statues refer to the national politics, while his statue quotes his poem "By the Danube", which in its finale advertises a fraternity of nations in the Carpathian basin.

On 13th July 2011 the Hungarian Parliament passed an act on the reconstruction of Kossuth Square, which contains the idea that one of the goals is to reconstruct "the square's artistic appearance of 1944." This idea, if taken seriously, would result in removing eight of the ten monuments, and brand new production of 286 replicas for statues perished long ago. The act, however, already emphasised that the

\footnotetext{
${ }^{4}$ See http://www.parlament.hu/irom39/03651/03651.pdf.
} 
memory of the victims of 25th October 1956 is an exemption, and the monuments concerning that event should stay. The monument of Mihály Károlyi (1875-1955), the president of the first Hungarian republic has already been removed by the time of the completion of this paper, but the fate of Attila József's statue is still under discussion due to civil protest. It would be surprising if a Hungarian government which makes every effort to emphasise its national commitment were to tolerate the presence of an object that seems to undermine the massive nationalist message encoded in the square. József is represented as a poet, making passers by remember that there are many other things to think about than national politics.

\section{References}

Bertényi, I. \& Gyapay, G. (1993). Magyarország rövid története. Budapest: Maenenas. Gerô, A. (2008). Téreró. A Kossuth tér története. Budapest: Új Mandátum. Romsics, I. (2000). Magyarország története a XX. Században. Budapest: Osiris. http://www.magyarulbabelben.net/works/hu/V\%C3\%B6r\%C3\%B6smarty_Mih\%C3\%A1ly/Sz\%C3\% B3zat/en/2135-Appeal?tr_id=519. 